\title{
Analisis Proses Pembelajaran E-Learning Berbasis Edmodo pada \\ Mata Kuliah Geometri
}

\author{
Fida Rahmantika Hadi ${ }^{1}$, Vivi Rulviana ${ }^{2}$ \\ FKIP UNIVERSITAS PGRI MADIUN \\ fidarahma47@gmail.com ${ }^{1}$, rulvianavivi@gmail.com²
}

\begin{abstract}
Abstrak
Penelitian ini merupakan penelitian kualitatif yang bertujuan untuk menganalisis proses pembelajaran e-learning berbasis edmodo dalam mata kuliah geometri pada mahasiswa semester 4 prodi PGSD Universitas PGRI Madiun. Subjek dalam penelitian ini adalah dosen matematika dan mahasiswa. Penelitian ini merupakan penelitian kualitatif. Data dalam penelitian ini diperoleh dari observasi. Teknik analisis data yang digunakan terdiri dari reduksi data, penyajian data, dan kesimpulan. Hasil penelitian ini adalah proses pembelajaran e-learning berbasis edmodo pada mata kuliah Geometri membuat pembelajaran matematika lebih menarik dan interaktif bagi mahasiswa serta membuat pembelajaran di kelas menjadi tidak membosankan. Selain itu, pembelajaran e-learning berbasis edmodo memiliki keuntungan diantaranya tidak memerlukan kelas formal dalam penerapannya.
\end{abstract}

Kata kunci: edmodo, e-learning, geometri

\begin{abstract}
This research is a qualitative research that aims to analyze the learning process of $e$ learning based on edmodo in geometry course on the 4th semester student of PGSD Study Program of University PGRI Madiun. Subjects in this study were lecturers of mathematics and students. This research is a qualitative research. The data in this study were obtained from observation. Data analysis techniques used consist of data reduction, data presentation, and conclusions. The result of this research is the learning process of e-learning based on edmodo in the subject of Geometry to make the learning of mathematics more interesting and interactive for the students and make the learning in the class become not boring. In addition, edmodobased e-learning learning has the advantage of not requiring a formal class in its application.
\end{abstract}

Keywords: edmodo, e-learning, geometry 


\section{PENDAHULUAN}

Pembelajaran merupakan sebuah sistem yang saling terhubung satu sama lain dimana terdiri atas materi, tujuan , motode dan evaluasi (Rusman, 2014: 1). Komponenkomponen dalam pembelajaran tersebut saling terkait antara satu dengan yang yang lainnya sehingga suatu perencanaan pembelajaran diperlukan dalam penerapan pembelajaran. Dalam perencanaan pembelajaran terdapat tiga faktor yang harus diperhatikan, yakni kondisi pembelajaran, metode pembelajaran dan hasil pembelajaran. Berdasarkan faktor tersebut, metode pembelajaran merupakan faktor yang dapat dimodifikasi oleh guru sesuai dengan kebutuhan pembelajaran. Dalam metode pembelajaran, guru dapat menggunakan beragam cara untuk bisa mencapai hasil pembelajaran yang sesuai dengan kondisi pembelajaran, termasuk dalam pemilihan media pembelajaran yang sesuai dengan kebutuhan pelajaran (Uno, 2008).

Guru dalam memilih metode pembelajaran yang sesuai dalam pembelajaran dapat menyesuaikan dengan kondisi kelas dan siswa yang akan menerima materi. Metode pembelajaran yang konvensional dewasa ini sudah jarang digunakan oleh guru karena minat siswa sangat kurang ketika proses pembelajaran berlangsung. Guru dituntut untuk dapat memanfaatkan teknologi dalam proses pembelajaran untuk menarik minat siswa agar siswa aktif dalam kegiatan pembelajaran yang berlangsung. Pemanfaatan teknologi dalam proses pembelajaran mendorong terciptanya beragam media pembelajaran yang bisa dipilih guru untuk digunakan dalam pembelajarannya. Hamalik (2011) menjelaskan bahwa teknologi adalah pembawa pesan yang dapat dimanfaatkan untuk keperluan pembelajaran.

Kemajuan dibidang teknologi informasi melahirkan konsep baru dalam pembelajaran yang berbasis IT atau yang lebih dikenal dengan e-learning. E-learning merupakan sistem pembelajaran elektronik yang memungkinkan peserta didik untuk dapat mengeksplorasi sekaligus juga dapat menjadi jembatan untuk melakukan pembelajaran kapan dan dimana saja (Zhang et.al., 2006). Pembelajaran dengan $e$ learning tidak terlepas dari penggunaan internet yang merupakan akses penting. Daryanto (2013) menjelaskan bahwa karena sifat internet yang dapat dihubungi setiap saat, artinya siswa dapat memanfaatkan program-program pendidikan yang disediakan di jaringan internet kapan saja sesuai dengan waktu luang mereka. E-learning dalam pelaksanaannya diperlukan sebuah media atau yang lebih dikenal dengan sebutan platform untuk menunjang kegiatan e-learning itu sendiri Salah satu platform yang dapat dimanfaatkan dalam proses pembelajaran e-learning adalah edmodo. Edmodo merupakan media sosial yang mendukung pembelajaran, dengan tampilan hampir serupa facebook. Menurut Zwang (2010), "edmodo adalah sebuah situs pendidikan berbasis social networking yang di dalamnya terdapat berbagai konten untuk pendidikan. Edmodo merupakan social network berbasis lingkungan sekolah (school based environment) yang dikembangkan oleh Nicolas Borg and Jeff O'Hara, dengan fitur-fitur pendukung proses belajar mengajar (Nurita, 2011). Fitur utama edmodo adalah dukungan aktif terhadap model komunikasi dari sosial media online, yang ditambahkan dengan fitur online learning material dan online evaluation. Meskipun 
Edmodo memiliki fitur-fitur yang hampir sama dengan facebook, dari segi kerahasiaan Edmodo lebih bersifat privasi.

Dalam proses pembelajaran Geometri masih sangat monoton dengan hanya menggunakan buku catatan, bahan fotocopian dan buku ajar. Dosen merupakan fasilitator terpenting dalam penyampaian ilmu kepada mahasiswa harus mampu berfikir kreatif di dalam menciptakan suasana pembelajaran agar ilmu yang akan ditransfer dapat diterima oleh mahasiswa dengan baik. Pada kenyataannya proses pembelajaran di kelas masih banyak yang belum memanfaatkan edmodo sebagai media e-learning. Proses pembelajaran yang masih manual membuat mahasiswa kurang aktif di dalam kelas. Padahal pembelajaran berasaskan laman web seperti edmodo ini amat baik serta berkesan terhadap mahasiswa karena mereka mampu membina pengetahuan baru dan bermanfaat kepada diri sendiri.

\section{METODE PENELITIAN}

Penelitian yang digunakan termasuk jenis penelitian kualitatif. Menurut Sugiyono (2012) penelitian kualitatif adalah metode penelitian yang digunakan untuk meneliti pada kondisi obyek yang alamiah, dimana peneliti adalah sebagai instrument kunci. Subjek penelitian ini adalah dosen dan mahasiswa Prodi PGSD Universitas PGRI Madiun. Sedangkan Objek dalam penelitian ini adalah media e-learning berbasis edmodo pada mata kuliah geometri di program studi PGSD di Universitas PGRI Madiun. Data dalam penelitian ini diperoleh peneliti dari observasi mahasiswa dan dosen matematika khususnya yang mengajar Geometri yang memiliki akun di edmodo. Sedangkan informasi dalam penelitian ini diperoleh dari berbagai peristiwa. Peneliti melakukan observasi langsung di lapangan dalam proses belajar mengajar Geometri.

Teknik analisis data yang digunakan adalah reduksi data, penyajian data, dan verifikasi dan penarikan kesimpulan. Validasi data menggunakan triangulasi (gabungan). Reduksi data yakni data yang telah diperoleh direduksi sehingga memberikan gambaran yang lebih jelas dan mempermudah peneliti untuk melakukan pengumpulan data. Penyajian data dilakukan dalam bentuk uraian singkat. Verifikasi dan penarikan kesimpulan merupakan temuan yang baru yang sebelumnya belum pernah ada. Temuan dapat berupa deskripsi atau gambaran suatu obyek yang sebelumnya masih remang-remang sehingga setelah diteliti menjadi jelas.

\section{HASIL DAN PEMBAHASAN}

Pembelajaran Geometri dengan memanfaatkan Edmodo sebagai media e-learning ini dimulai dengan penyampaikan kontrak kuliah yang dilakukan oleh dosen serta penyampaian dan pengarahan berkenaan dengan edmodo yang akan dimanfaatkan dalam proses pembelajaran yang akan dilaksanakan dalam waktu satu semester.

Selanjutnya melakukan pembuatan grup, yang terdiri dari mahasiswa prodi PGSD semester 4 yang kemudian dikelompokkan berdasarkan kelasnya masing-masing yaitu kelas A dan B. Hal ini bertujuan agar pada saat dosen memberikan tugas kepada mahasiswa, tidak tercampur dengan kelas yang lain dan hal tersebut mempermudah 
proses pengerjaan nilai. Mahasiswa juga bisa saling memberikan pendapatnya pada grup tersebut. Grup yang telah dibuat merupakan sarana penyampaian materi yang diajarkan. Kemudian menambahkan anggota yang terdiri dari mahasiswa yang berada di kelas tersebut.

Pembelajaran dengan memanfaatkan media e-learning berbasis edmodo merupakan pembelajaran yang tidak memerlukan kelas formal untuk proses pembelajarannya. Ketika dosen menyempaikan materi lewat edmodo maka siswadapat membacanya dimanapun mereka berada. Para mahasiswa memiliki kebebasan untuk dapat mengakses dan mempelajari materi sesuai dengan keinginan mereka masingmasing. Hal tersebut sesuai dengan yang diutarakan Ibu Rissa selaku dosen geometri. Melalui edmodo, dosen dapat menyampaikan materi atau tugas pada grup yang telah dibuat tersebut, dengan menyebutkan kelas dan judul materi yang disampaikan. Mahasiswa dapat memberikan komentar atau tanggapan terhadap materi yang disampaikan tersebut pada tempat untuk menulis komentar.

Pembelajaran geometri yang dilakukan dengan edmodo sebagai media $e$ learning di kelas digunakan ketika dosen akan memberikan materi bangun ruang. Sebelum memberikan materi, biasanya dosen mengirim materi tersebut ke edmodo sehari sebelumnya sehingga mahasiswa dapat mempelajari materi tersebut. Pada hari berikutnya ketika proses pembelajaran pada materi bangun ruang yang dipelajari, mahasiswa lebih mudah mengerti. Ini dibuktikan ketika dosen memberikan latihanlatihan soal, mahasiswa mampu menyelesaikannya dengan baik. Pembelajarn geometri dengan menggunakan media edmodo diyakini telah berhasil membuat pembelajaran matematika yang menarik dan interaktif bagi mahasiswa serta membuat pembelajaran di kelas menjadi lebih menarik. Edmodo digunakan dosen selain sebagai sarana untuk menginformasikan materi juga sebagai sarana untuk menyampaikan tugas-tugas yang bisa dikerjakan oleh peserta didik.

Geometri merupakan salah satu mata kuliah elemen kompetensi keterampilan dan keahlian.Geometri secara umum dinilai cukup sulit oleh mahasiswa program studi PGSD.Dalam mempelajari geometri, tentunya memerlukan perhatian dari dosen agar mahasiswa tertarik dan mampu mencapai target yang telah ditentukan.Secara umum dilihat dari perspektif mahasiswa, geometri merupakan ilmu yang melulu soal angka, pengukuran, kurang menyenangkan, dan kaku. Namun, meskipun termasuk pembelajaran yang kaku tetapi kekakuan tersebut dapat diatasi dengan adanya suatu kreasi yang dilakukan oleh dosen dengan adanya suatu metode pengajaran atau bisa dengan adanya pemanfaatan media pembelajaran sebagai perantara suatu proses pembelajaran.

Pembelajaran mata kuliah geometri di prodi PGSD Universitas PGRI Madiun khususnya kelas a dan b dimana yang merupakan mahasiswa dari dosen geometri yang bernama ibu Rissa Prima, disitu dalam proses pembelajaran memanfaatkan suatu media dalam proses pembelajaran mata kuliah geometri di dalamnya. Proses pembelajaran yang dilakukan meskipun termasuk mata kuliah yang kaku namun terlihat santai dan menciptakan suasana belajar yang nyaman karena memanfaatkan media yang tergolong 
terkini karena mengikuti perkembangan teknologi sekarang ini. Pembelajaran mata kuliah geometri di kelas bu Rissa memanfaatkan media pembelajaran e-learning berbasis edmodo yang dimana media tersebut merupakan termasuk media yang memudahkan anak-anak khususnya di taraf remaja ke atas untuk dapat belajar dengan nyaman sesuai waktu dan tempat yang diinginkan si pelajar.

Proses pembelajaran mata kuliah geometri dengan memanfaatkan media pembelajaran e-learning berbasis edmodo yang dilakukan oleh ibu Rissa Prima di kelas yang di ampu beliau dimulai dengan mengisi pertemuan pertama dengan memberikan penjelasan berkenaan dengan kontrak perkuliahan yang akan disampaikan beliau dalam kurun waktu satu semester tersebut kepada para mahasiswa dan memberikan arahan serta penjelasan berkenaan dengan e-learning berbasis edmodo yang digunakan sebagai media pembelajaran dalam mata kuliah yang beliau ampu tersebut. Selanjutnya setelah para mahasiswa dirasa telah paham dengan pengarahan yang dosen berikan dilanjutkan dengan pembuatan grup dalam edmodo tersebut yang akan dimanfaatkan sebagai saranan atau media pembelajaran selama satu semester dalam mata kuliah geometri yang ibu Rissa Prima ampu tersebut. Pembuatan grup dilakukan secara terpilah antara kelas a dan kelas b. Hal tersebut dilakukan apabila dosen akan mengupload tugas kepda para mahasiswa maka jawaban yang diupload mahasiswa tidak tercampur dan dapat mempermudah dosen dalam hal proses pengerjaan nilai.

Grup yang telah dibuat merupakan sarana penyampaian materi yang diajarkan. Kemudian menambahkan anggota yang terdiri dari mahasiswa yang berada di kelas tersebut. Pembelajaran dengan memanfaatkan media e-learning berbasis edmodo merupakan pembelajaran yang tidak memerlukan kelas formal untuk proses pembelajarannya. Ketika dosen menyempaikan materi lewat edmodo maka siswa dapat membacanya dimanapun mereka berada. Para mahasiswa memiliki kebebasan untuk dapat mengakses dan mempelajari materi sesuai dengan keinginan mereka masingmasing. Melalui edmodo, dosen dapat menyampaikan materi atau tugas pada grup yang telah dibuat tersebut, dengan menyebutkan kelas dan judul materi yang disampaikan. Mahasiswa dapat memberikan komentar atau tanggapan terhadap materi yang disampaikan tersebut pada tempat untuk menulis komentar.

Pelaksanaan pembelajaran menggunakan media e-learning berbasis edmodo ketika dosen geometri akan menyampaikan materi berkenaan dengan bangun ruang, Sebelum memberikan materi, biasanya dosen mengirim materi tersebut ke edmodo sehari sebelumnya sehingga mahasiswa dapat mempelajari materi tersebut. Pada hari berikutnya ketika proses pembelajaran pada materi bangun ruang yang dipelajari, mahasiswa lebih mudah mengerti. Ini dibuktikan ketika dosen memberikan latihanlatihan soal, mahasiswa mampu menyelesaikannya dengan baik. Pembelajarn geometri dengan menggunakan media edmodo diyakini telah berhasil membuat pembelajaran matematika yang menarik dan interaktif bagi mahasiswa serta membuat pembelajaran di kelas menjadi lebih menarik. 


\section{KESIMPULAN}

Geometri merupakan salah satu mata kuliah elemen kompetensi keterampilan dan keahlian yang dinilai cukup sulit oleh mahasiswa program studi PGSD karena dilihat dari perspektif mahasiswa, geometri merupakan ilmu yang melulu soal angka, pengukuran, kurang menyenangkan, dan kaku. Oleh karena itu penerapan e-learning berbasis edmodo membuat proses pembelajaran terlihat santai dan menciptakan suasana belajar yang nyaman. Proses pembelajaran diawali dengan kontrak kuliah dan penjelasan mengenai proses pembelajaran e-learning berbasis edmodo yang akan dilakukan selama satu semester. Selanjutnya, setelah para mahasiswa dirasa telah paham dengan pengarahan yang dosen berikan dilanjutkan dengan pembuatan grup dalam edmodo yang dilakukan dengan mengelompokkkan mahasiswa berdasarkan kelasnya masing-masing. Pembelajaran geometri yang dilakukan dengan edmodo sebagai media e-learning di kelas digunakan ketika dosen akan memberikan materi bangun ruang yang dikirim sehari sebelum proses pembelajaran dalam kelas berlangsung. Edmodo digunakan dosen selain sebagai sarana untuk menginformasikan materi juga sebagai sarana untuk menyampaikan tugas-tugas yang bisa dikerjakan oleh peserta didik. Pembelajaran dengan memanfaatkan e-learning berbasis edmodo sebagai media memang memiliki banyak sekali keuntungan. Pembelajaran dengan memanfaatkan media e-learning berbasis edmodo merupakan pembelajaran yang tidak memerlukan kelas formal untuk proses pembelajarannya.

\section{DAFTAR PUSTAKA}

Daryanto. (2013). Media Pembelajaran, Peranannya Sangat Penting dalam Mencapai Tujuan Pembelajaran. Yogyakarta: Gava Media.

Nurita Putranti. (2013). Cara Membuat Media Pembelajaran Online Menggunakan Edmodo.Jurnal Pendidikan Informatika dan Sains, 2(2).Hlm. 141.

Oemar Hamalik. (2011). Kurikulumdan Pembelajaran. Jakarta: BumiAksara.

Rusman. (2014). Model-model Pembelajaran. Jakarta : Raja GrafindoPersada

Seamolec.(2013). Buku Sumber Simulasi Digital. Jakarta: Seamolec.

Sugiyono. (2012). Metode Penelitian Kuantitatif Kualitatif \& RND. Bandung: Alfabeta

Zhang, D., Zhou, L., \& Briggs, R. (2006). Instructional video in e-learning: Assessing the impact of interactive video on learning effectiveness. Information \&Management.Vol. 43.Issue 1. p. 15-27.

Zwang, J. (2010). Edmodo:A Free, Secure, Social Networking Site For School. (Online), (http://www.eschoolnews.com/2010/12/15/edmodo-a-free-secure-social networkingsitefor-school/. Diakses 8 Desember 2016) 